\title{
DOES COLOSTOMY RESTORATION INCREASE THE RISK OF DEVELOPING A SUBSEQUENT RECTAL CANCER?
}

\author{
Bogdan SOCEA ${ }^{1^{*} \bowtie}$, Ovidiu G. BRATU ${ }^{2}$, Camelia DIACONU ${ }^{3}$, Laura I. SOCEA ${ }^{4}$, \\ Mihai DIMITRIU ${ }^{5}$, Alexandru C. CARÂP ${ }^{1}$, Anca A. NICA ${ }^{1}$, Alexandru SMARANDA ${ }^{1}$, \\ Cezar E. MOCULESCU ${ }^{1}$, Vlad D. BĂLEANU ${ }^{1}$, Dragoș DAVIṬOIU ${ }^{1}$, Vlad D. CONSTANTIN ${ }^{1}$
}

${ }^{1}$ "Carol Davila“ University of Medicine and Pharmacy, General Surgery Clinic, Emergency Clinical Hospital "Sfântul Pantelimon", Bucharest, Romania

2 „Carol Davila“ University of Medicine and Pharmacy, Department of Urology, Emergency Universitary Central Military Hospital, Bucharest, Romania

3 "Carol Davila“ University of Medicine and Pharmacy, Internal Medicine Clinic, Clinical Emergency Hospital of Bucharest, Bucharest, Romania

${ }^{4}$ "Carol Davila“ University of Medicine and Pharmacy, Organic Chemistry Department, Faculty of Pharmacy, Bucharest, Romania

5 „Carol Davila“ University of Medicine and Pharmacy, Obstetrics and Gynecology Clinic, Emergency Clinical Hospital "Sfântul Pantelimon", Bucharest, Romania

Received 05 June 2018, Accepted 29 July 2018

https://doi.org/10.31688/ABMU.2018.53.3.09

\section{Abstract}

Introduction. In the last five years (from $1^{\text {st }}$ of January 2013 to $31^{\text {st }}$ of December 2017), we noticed 6 cases of rectal cancer, developed in patients who underwent stoma reversal more than two years before, for different pathologies.

The objective of the study. That was a starting point to analyze whether the restoration of a total digestive diversion, well known to improve life quality, also increases the risk of malignancy. Material and methods. We studied all the patients with colostomy reversal hospitalized in the General Surgery Clinic of the Emergency Clinical Hospital "Sfântul Pantelimon", Bucharest, Romania, in a ten years interval ( $1^{\text {st }}$ of January 2008 - 31 $1^{\text {st }}$ of December 2017), no matter the primary cause of colostomy was.

\section{Résumé}

La restauration de la colostomie augmente-t-elle le risque de développer un cancer rectal postérieur?

Introduction. Au cours des cinq dernières années (du 1er janvier 2013 au 31 décembre 2017), nous avons observé 7 cas de cancer du rectum, développés chez des patients ayant subi une inversion du stoma il y a deux ans, pour différentes affections.

Objectifs. C'était un point de départ pour analyser si la restauration du détournement digestif, bien connu pour améliorer la qualité de vie, augmentait également le risque de malignité.

Méthodes. Nous avons étudié tous les patients présentant une inversion de la colostomie hospitalisés à la 
Results. Our study showed that stoma reversal increased the risk of developing a rectal malignancy two years from restoration.

Conclusions. We recommend annual control by recto-sigmoidoscopy both in patients with terminal permanent colostomy and in those with stoma reversal, in order to early discover a subsequent rectal cancer.

Key words: colostomy restoration, stoma reversal, rectal cancer risk.

\section{INTRODUCTION}

There are lots of particular situations that require, at the first time of operation, colostomy diversion instead of colic anastomosis, with high risk of dehiscence. The colostomy is often a temporary procedure, those patients being re-operated to reestablish the normal digestive continuity, at a variable time interval. It is well known that permanent colostomy affects the quality of life and social reintegration. Self-management support is broader than health services alone ${ }^{1}$. Thus, the wish of reversal is justifiable. But is this costless?

In literature, stoma reversal itself has not been reported as a risk factor for rectal cancer. There is a recent article that shows an increased risk of infection with Clostridium difficile after stoma restoration ${ }^{2}$.

The obJective OF THE STUdY was to analyze whether the restoration of a total digestive diversion, wellknown to improve life quality, also increases the risk of malignancy".

\section{Material ANd Methods}

The study took place in the Sf. Pantelimon Clinical Hospital", Bucharest, Romania. After obtaining approval from the Ethical Committee of „Sf. Pantelimon Clinical Hospital“, Bucharest, Romania, we retrospectively analyzed 83 patients who underwent stoma reversal in the Surgery Clinic of our hospital over a 10 years period, between January 2008 and December 2017 (cohort A). All the patients signed an informed consent.

The inclusion criteria were represented by all patients who underwent colostomy restoration in our centre, between January 2008 and December 2017, no
Clinique de Chirurgie Générale de L'Hôpital Clinique d'Urgence "Sfantul Pantelimon", Bucarest, Roumanie, dans un intervalle de dix ans (du 1er janvier 2008 au 31 décembre 2017), quelle que soit la cause première de la colostomie.

Résultats. Notre étude a montré que l'inversion du stoma augmentait le risque de développer une malignité rectale suite à la restauration.

Conclusions. Nous recommandons un contrôle annuel par recto-sigmoïdoscopie chez les patients présentant une colostomie définitive en phase terminale et chez ceux présentant une inversion de stomie, afin de détecter rapidement un cancer rectal ultérieur.

Mots-clés: restauration de la colostomie, inversion de la stomie, risque de cancer du rectum.

matter the primary diagnosis was, except rectal cancer. We excluded patients with rectal cancer who underwent Hartmann procedure, followed by restoration, because a late development of rectal cancer could be interpreted as a local recurrence in these patients.

We compared the data with those of a similar cohort of 72 patients from the same period, who underwent only Hartmann procedure, without restoration (cohort B). For the similarity of the cohorts, we neither included in cohort B patients with rectal cancer. The lack of reversal was due to several reasons: age, a short rectal remnant segment, other important co-morbidities, the evolution of malignant disease itself.

Regarding the method, our study is retrospective, observational. We collected the data from the patient charts, laboratory results, supplemental imaging studies (abdominal ultrasound, computed tomography - CT), surgery recordings, histological results.

\section{Results AND DISCUSSION}

Cohorts A and B are relatively similar regarding sex ratio and age distribution. The medical cause for primary surgical procedure was mostly neoplastic disease for cohort B.

Thus, sex ratio (M:F) was 1.08 for cohort A, respectively 1.11 for $\mathrm{B}$. The mean age was 60.6 years for group A and 64.7 years for group B.

The age distribution of patients is shown in Figure 1. We can notice a slightly higher prevalence of elder ages in group B, that being the very reason of no-reversal plan in some cases. Associated diagnosis, with high anesthetic and operative risks, also determined us to keep some colostomy as definitive, as it was for some patients with impaired renal func$\operatorname{tion}^{3.5}$. The other causes for a definitive colostomy 
were: patient refuse for a reintervention, metastatic disease, colostomy for fistula, malignant adhesion syndrome.

The optimal time for stoma reversal is discussed in literature. Our time was 3-9 months for non-neoplastic disease, respectively $12-36$ months for neoplastic disease. Time to stoma closure is often nearly doubled when patients underwent adjuvant chemotherapy ${ }^{6}$.

The causes of primary intervention with terminal colostomy are mentioned in Table 1 (neoplastic and non-neoplastic causes). The neoplastic disease (sigmoid or descending colon adenocarcinoma) was present in 45 patients of group B (62.5\%), compared to 37 patients from cohort $\mathrm{A}(44.5 \%)$. The main reason of no-reversal was the malignant disease. A free of disease interval of minimum 12 months is the best timing for colostomy restoration. Our option for all the 83 reversals was laparotomy, the rate of laparoscopic stoma reversal after Hartmann procedure being low in literature, as well?

Among the rare cases of temporary colostomy, followed by restoration, there were two cases of sigmoid invagination in elderly, which is a rare condition $^{8}$. Women pelvic surgery has definitely some particularities. In one case of non-reversal cohort (B), we confronted with a uro-vaginal fistula, a condition hard to manage'. A vulvar squamous carcinoma was noted in a patient, that required adjacent surgical treatment ${ }^{10}$.

All the patients with stoma reversal were scheduled for follow up visits at 1 year, 2 years, 3 and 5 years intervals. We diagnosed 6 cases of new developed rectal cancer between 2013 and 2017. The mean interval of primary diagnosis after reversal time was 43 months (with limits 24 and 60 months).
All the 6 cases underwent preoperative radiotherapy. 3 cases achieved complete clinical remission (clinic and at magnetic resonance imaging - MRI) after radiation, from which one of them underwent an anterior rectal resection with colostomy; the other two refused the surgical treatment. Thus, for those two we proposed the "watch and wait" management ${ }^{11}$. All the patients had a good evolution at one year and two years follow up.

Another three cases achieved only partial remission after radiotherapy. They were referred to surgical interventions: one low anterior rectal resection ${ }^{12}$ and two abdominoperineal resections, all followed by colostomy.

From cohort B, we encountered only one case of rectal cancer at 16 months after a primary sigmoidectomy with terminal colostomy for acute diverticulitis.

Comparing the results of developing rectal cancer -6 cases in cohort A $(7.2 \%)$ vs. one case in cohort B $(1.38 \%)$, the difference we found is statistically significant.

The main limits of this study are related to the lack of long time follow-up of several patients.

We could not establish whether the onset of subsequent rectal cancer in these patients was preceded by the existence of rectal adenomatous polyps that transformed ${ }^{13,14}$. It would be a valuable issue in a future prospective study.

\section{Conclusions}

We noticed an increased risk of subsequent rectal cancer in patients with stoma reversal. This could be related to aggressive substances from stool (free radicals), maintaining of alimentary habits that led also to primary neoplasm, or malignant degeneration of a pre-existent rectal adenomatous polyp. We

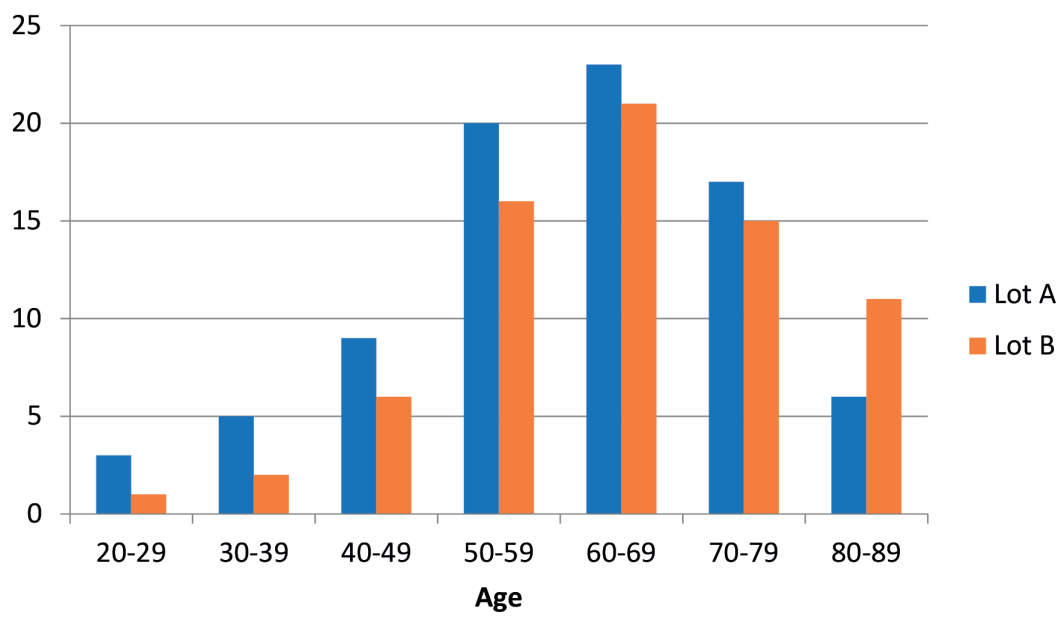

Figure 1. Comparative age distribution of the two cohorts of patients 
Table 1. Diagnosis at the time of the first intervention

\begin{tabular}{ccc}
\hline & Cohort A & Cohort B \\
\hline Sigmoid/descending colon neoplasm & 37 & 45 \\
\hline Acute diverticulitis & 23 & 16 \\
\hline Sigmoid volvulus & 7 & 4 \\
\hline Infectious colitis, ulcerative colitis & 5 & 1 \\
\hline Colic perforation & 5 & 0 \\
\hline Another rare causes & 6 & 6 \\
\hline
\end{tabular}

definitely need more prospective studies to conclude this.

The mean time of onset of rectal cancer after stoma reversal was 43 months. All the patients developed rectal cancer after a minimum two years free time interval from restoration. That excludes either a local recurrence, or a synchronous rectal neoplasm from the very first time.

We strongly recommend annual control by recto-sigmoidoscopy both in patients with terminal permanent colostomy and in those with stoma reversal, in order to early discover a subsequent rectal cancer. As well, both after colostomies in emergency conditions for different diagnosis, and before reversal procedures, we recommend to perform a rectoscopy or a rectosigmoidoscopy to diagnose and endoscopically resect the polyps eventually present.

\section{Compliance with Ethics Requirements:}

„The authors declare no conflict of interest regarding this article"

„The authors declare that all the procedures and experiments of this study respect the ethical standards in the Helsinki Declaration of 1975 , as revised in 2008(5), as well as the national law. Informed consent was obtained from all the patients included in the study"

"No funding for this study"

\section{References}

1. Ribarov R, Vodenicharov T, Ivanov A, Ivanova N. Necessity of self-management support following colorectal cancer treatment. Arch Balk Med Union 2017;52(3):285-90.

2. Skancke M, Vaziri K, Umapathi B, Amdur R, Radomski $\mathrm{M}$, Obias V. Elective stoma reversal has a higher incidence of postoperative Clostridium difficile infection compared with elective colectomy: an analysis using the American
College of Surgeons National Surgical Quality Improvement Program and Targeted Colectomy Databases. Dis Colon Rectum 2018;61(5):593-598.

3. Peride I, Rădulescu D, Niculae A, Ene V, Bratu OG, Checheriță IA. Value of ultrasound elastography in the diagnosis of native kidney fibrosis. Med Ultrason 2016; 18(3): $362-9$.

4. Niculae A, Peride I, Marinescu-Paninopol A, et al. Renal artery bilateral arteriosclerosis cause of resistant hypertension in hemodialysed patients. Rom J Morphol Embryol 2016; 57(2):591-4.

5. Checheriță IA, Smarandache D, Rădulescu D, et al. Calcific uremic arteriolopathy in hemodialyzed patients. Chirurgia (Bucur) 2013;108(5):736-40.

6. Herrle F, Sandra-Petrescu F, Weiss C, Post S, Runkel N, Kienle P. Quality of life and timing of stoma closure in patients with rectal cancer undergoing low anterior resection with diverting stoma: a multicenter longitudinal observational study. Dis Colon Rectum 2016;59(4):281-90.

7. Parkin E, Khurshid M, Ravi S, Linn T. Surgical access through the stoma for laparoscopic reversal of Hartmann procedures. Surg Laparosc Endosc Percutan Tech 2013;23(1):41-4.

8. Socea B, Nica AA, Bratu $O$, et al. Incidental finding of a sigmoid intussusception associated with rectal prolapse - a case report. Arch Balk Med Union 2018;53(1):143-6.

9. Bodean $\mathrm{O}$, Bratu OG, Munteanu $\mathrm{O}$, et al. Iatrogenic injury of the low urinary tract in women undergoing pelvic surgical interventions. Arch Balk Med Union 2018;53(2): 281-284.

10. Cozma CN, Raducu L, Avino A, et al. A rare case of vulvar squamos cell carcinoma; case presentation. J Clin Invest Surg 2018;3(1):32-36.

11. Hupkens BJP, Martens MH, Stoot JH, et al. Quality of life in rectal cancer patients after chemoradiation: watch-and-wait policy versus standard resection - a matched-controlled study. Dis Colon Rectum 2017;60(10):1032-1040.

12. Păduraru DN, Pițuru SM, Bolocan A, Marin I, Andronic O. Surgical management of patients with rectal neoplastic disease - Prediction factors in low anterior resection syndrome. Arch Balk Med Union 2017;52(4): 414-21.

13. Dumitras IC. Ionescu C, Bartos D, Diaconu C. The diagnosis of malignat disease: sometimes a matter of pure chance. Arch Balk Med Union 2017;52(1):112-116.

14. Ginghina $\mathrm{O}$, Negrei $\mathrm{C}$, Hudita A, et al. In vitro impact of some natural compounds on HT-29 colorectal adenocarcinoma cells. Farmacia 2017;65(6):947-953. 